\section{Pacific Northwest}

National Laboratory

Operated by Battelle for the

U.S. Department of Energy

\title{
Urban Dispersion Program MSG05 Field Study: Summary of Tracer and Meteorological Measurements
}

K. J. Allwine

J. E. Flaherty

August 2006

Prepared for the U.S. Department of Homeland Security under a Related Services Agreement with the U.S. Department of Energy under contract DE-AC05-76RL01830 


\title{
DISCLAIMER
}

This report was prepared as an account of work sponsored by an agency of the United States Government. Neither the United States Government nor any agency thereof, nor Battelle Memorial Institute, nor any of their employees, makes any warranty, express or implied, or assumes any legal liability or responsibility for the accuracy, completeness, or usefulness of any information, apparatus, product, or process disclosed, or represents that its use would not infringe privately owned rights. Reference herein to any specific commercial product, process, or service by trade name, trademark, manufacturer, or otherwise does not necessarily constitute or imply its endorsement, recommendation, or favoring by the United States Government or any agency thereof, or Battelle Memorial Institute. The views and opinions of authors expressed herein do not necessarily state or reflect those of the United States Government or any agency thereof.

\author{
PACIFIC NORTHWEST NATIONAL LABORATORY \\ operated by \\ BATTELLE \\ for the \\ UNITED STATES DEPARTMENT OF ENERGY \\ under Contract DE-ACO5-76RL01830
}

Printed in the United States of America

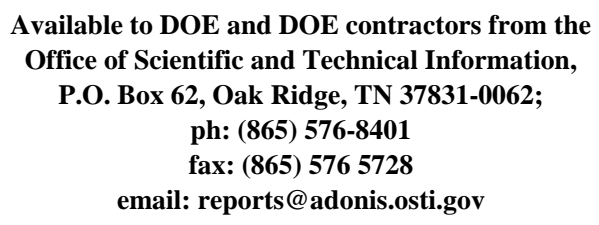

Available to DOE and DOE contractors from the Office of Scientific and Technical Information, P.O. Box 62, Oak Ridge, TN 37831-0062; ph: (865) 576-8401 fax: (865) 5765728

email: reports@adonis.osti.gov

\author{
Available to the public from the National Technical Information Service, \\ U.S. Department of Commerce, 5285 Port Royal Rd., Springfield, VA 22161 \\ ph: (800) 553-6847 \\ fax: (703) 605-6900 \\ email: orders@nits.fedworld.gov \\ online ordering: http://www.ntis.gov/ordering.htm
}




\title{
Urban Dispersion Program MSG05 Field Study: Summary of Tracer and Meteorological Measurements
}

\author{
K. J. Allwine \\ J. E. Flaherty
}

August 2006

Prepared for the U.S. Department of Homeland Security under a Related Services Agreement with the U.S. Department of Energy under Contract DE-AC05-76RL01830

Pacific Northwest National Laboratory

Richland, Washington 99352 


\section{Summary}

The Urban Dispersion Program (UDP) is a multi-year project, funded by the U.S. Department of Homeland Security, to better understand the flow and dispersion of airborne contaminants through and around the deep street canyons of New York City. The first UDP tracer and meteorological field study was a limited study conducted during March 2005 near the Madison Square Garden (MSG) in midtown Manhattan. The study is designated MSG05 where six safe, inert, gaseous perfluorocarbon tracers (PFTs) were released simultaneously at five street-level locations (two PFTs were co-located for quality control) during two experimental days. PFT samples were collected by several tracer samplers located at streetlevel and on buildings around MSG. Additionally, some types of tracer samplers were located indoors, and other types (personal air samplers) were carried along prescribed paths by project staff measuring the tracer exposure along the various paths. The total study area was approximately 1-km-by-1-km centered on the MSG.

In addition to collecting tracer data, meteorological data were also collected. These included sonic anemometer data from six street-level locations around MSG. Sonic anemometers were also deployed at three building setback locations and three building rooftop locations. A sodar for measuring the vertical profile of winds was positioned on the Farley Post Office, just west of MSG, as well as at two locations across the Hudson River at the Stevens Institute of Technology (SIT) in Hoboken, New Jersey. Additional meteorological data were collected from several permanent stations on Manhattan as well as from nearby automated surface observing systems operated by the National Weather Service.

Brookhaven National Laboratory (BNL) conducted the bulk of the tracer and meteorological field efforts with Pacific Northwest National Laboratory and SIT assisting by measuring the vertical profile of winds at the SIT campus. The Environmental Protection Agency worked with BNL in accomplishing the personal exposure component of the study. This report is a companion to the two BNL MSG05 reports giving details of the tracer and meteorological components of the study. This report gives the coordinates of all the instruments deployed for this field study geo-referenced to a detailed building database. The coordinates were defined by positioning the instruments within a geographic information systems map using the detailed building and roads databases for the midtown Manhattan area. A quality-assured tracer dataset was developed as a subset of the complete tracer dataset for direct use in dispersion model validation studies. These data were carefully analyzed to assess internal consistency. This report presents some results from this analysis. In general, different release locations showed vastly different plume footprints for tracer materials, and the situation was made very complex with upwind and/or crosswind transport of tracer near street-level for the different release locations. Overall wind speeds and directions upwind and over the city were generally constant throughout each of the two experimental periods.

The MSG05 tracer data (release rates and concentrations) currently have limited distribution, and will only be distributed with a need-to-know. This report does not give any quantitative tracer release or concentration information, so it will be available for general distribution. 



\section{Acronyms}

\begin{tabular}{|c|c|}
\hline AMSL & above mean sea level \\
\hline ASOS & automated surface observing system \\
\hline $\mathrm{AV}$ & AeroVironment sodar \\
\hline BNL & Brookhaven National Laboratory \\
\hline BATS & Brookhaven atmospheric tracer sampler \\
\hline CDTA & continuous dual trap analyzer \\
\hline DHS & Department of Homeland Security \\
\hline EST & Eastern Standard Time \\
\hline GIS & geographic information system \\
\hline IOP & intensive observation period \\
\hline MSG & Madison Square Garden \\
\hline NAD & North American Datum \\
\hline NOAA & National Oceanic and Atmospheric Administration \\
\hline NYC & New York City \\
\hline NWS & National Weather Service \\
\hline PAS & personal air sampler \\
\hline PFT & perfluorocarbon tracer \\
\hline PNNL & Pacific Northwest National Laboratory \\
\hline SAS & sequential air sampler \\
\hline SIT & Stevens Institute of Technology \\
\hline UDP & Urban Dispersion Program \\
\hline UTM & Universal Transverse Mercator \\
\hline WDIR & wind direction \\
\hline WSPD & wind speed \\
\hline
\end{tabular}





\section{Acknowledgments}

This research was supported in part by the U.S. Department of Homeland Security under a Related Services Agreement with the U.S. Department of Energy (DOE) under Contract DE-AC05-76RL01830. Pacific Northwest National Laboratory is operated for DOE by Battelle.

The Urban Dispersion Program's MSG05 field study would not have been possible without the support of New York City (NYC) agencies, private land owners, and the general public. Mr. Kevin Clark of the NYC Office of Emergency Management was instrumental in the success of MSG05 by spearheading many of the needed logistical arrangements and operating permissions. The support of Dr. Tony Fainberg (Department of Homeland Security program manager) and Rick Fry (Defense Threat Reduction Agency program manager) was much appreciated. The easy collaboration of Urban Dispersion Program team members, various NYC staff, private land owners, and local university students and faculty was essential for the success of the study. Further acknowledgments to successfully accomplishing MSG05 are given in the Brookhaven National Laboratory (BNL) companion tracer report (Watson et al. 2006) as well as in Berg and Allwine (2006).

A number of key individuals provided the necessary information and feedback to develop the refined instrument coordinates that are presented in this report. Mr. John Heiser and Dr. Tom Watson of BNL provided information on tracer sampler locations, and Dr. Michael Reynolds and Mr. Victor Cassella, also of BNL, assisted with meteorological instrument coordinates. Dr. Steve Hanna of the Harvard School of Public Health helped with the quality assessment of the tracer and meteorological data. 



\section{Contents}

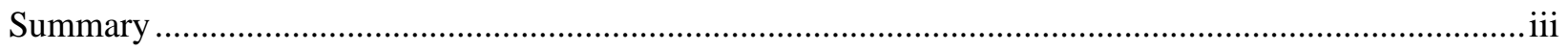

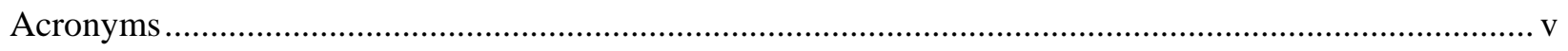

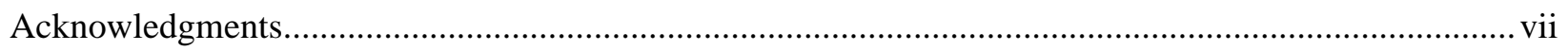

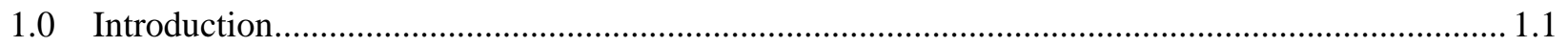

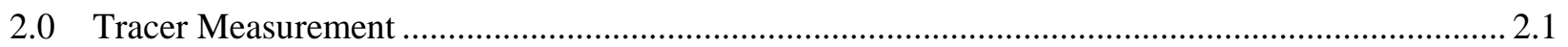

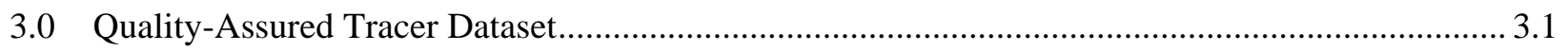

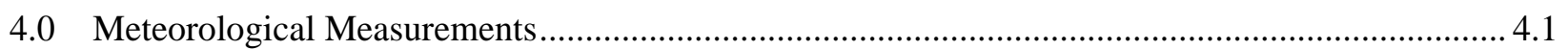

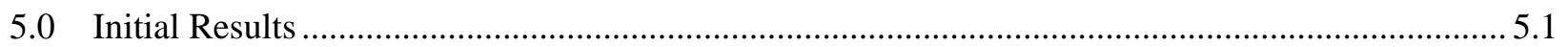

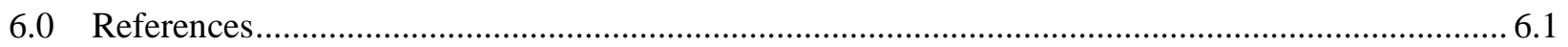




\section{Figures}

2.1. Perfluorocarbon Tracer Release Locations ................................................................................... 2.1

2.2. Outdoor Perfluorocarbon Tracer Sampler Locations................................................................... 2.2

4.1. Sonic Anemometer Locations in the Vicinity of MSG ............................................................. 4.1

4.2. Meteorological Stations in the Vicinity of Manhattan................................................................. 4.2

4.3. Overview of All Meteorological Stations in the Vicinity of NYC ............................................... 4.2

5.1. IOP 1 Winds from (a) the 90 -m Level (175m above mean sea level [AMSL]) of the AeroVironment (AV) Sodar at SIT, Rooftop Meteorological Stations at (b) One Penn Plaza (240m AMSL), (c) Farley Post Office (47m AMSL), and (d) Two Penn Plaza (146m AMSL)

5.2. IOP 1 Winds from the Street Level Sonic Anemometers Surrounding MSG on the (a) Northwest, (b) Northeast, (c) Southwest, and (d) Southeast Corners

5.3. IOP 1 Plume Contours Based on the Average of Two Separate Hours of Tracer Release for Various Release Locations.

5.4. IOP 2 Winds from (a) the 90-m Level (175m AMSL) of the AV Sodar at SIT, Rooftop Meteorological Stations at (b) One Penn Plaza (240m AMSL), (c) Farley Post Office (47m AMSL), and (d) Two Penn Plaza (146m AMSL)

5.5. IOP 2 Winds from the Street Level Sonic Anemometers Surrounding MSG on the (a) Northwest, (b) Northeast, (c) Southwest, and (d) Southeast Corners

5.6. IOP 2 Plume Contours Based on the Average of Two Separate Hours of Tracer Release for Various Release Locations. 5.6

\section{Tables}

2.1. Release Location Coordinates 2.1

2.2. Brookhaven Sampler Coordinates 2.3

4.1. Meteorological Instrument Coordinates 4.3 


\subsection{Introduction}

The Urban Dispersion Program (UDP), a multi-year program that began during early 2004, is aimed at investigating air flow and atmospheric dispersion through the heavily urbanized Manhattan borough of New York City (NYC). The UDP will collect ground-truth dispersion data that will be used to develop and validate tools to aid planners and first responders in the event of a contaminant release into the atmosphere of Manhattan. The Madison Square Garden (MSG) dispersion study, conducted during March 2005 (designated MSG05), was the first field study conducted under the UDP. A second, more extensive field study was conducted in Midtown during August 2005 (MID05). The MID05 study will not be discussed in this report.

The MSG05 tracer and meteorological field study was conducted in Midtown, Manhattan, in an approximately 1-km by 1-km domain centered on the MSG. The MSG05 comprised of two intensive observation periods (IOPs), where each IOP was conducted from 0900 to 1400 Eastern Standard Time (EST). During an IOP, six safe, inert, gaseous perfluorocarbon tracers (PFTs) were released simultaneously at five near-surface sites around the MSG. In addition to 19 outdoor ground-level sampling locations, several indoor and rooftop sites were sampled, and personal exposure measurements were made. Two 1-hour-long continuous releases of PFTs were conducted during each IOP. These occurred from 0900 to 1000 EST and from 1130 to 1230 EST. The two IOPs were conducted on March 10 and 14, 2005.

Data from meteorological measurements at a number of locations are available to support this study. Sonic anemometers were deployed at six ground-level locations around MSG as well as at three building setback locations and three building rooftop locations. A sodar was positioned on the Farley Post Office, just west of MSG, as well as at two locations across the Hudson River at the Stevens Institute of Technology in Hoboken, New Jersey. Additional meteorological data are available from several permanent stations on Manhattan as well as from nearby automated surface observing systems (ASOSs) operated by the National Weather Service (NWS).

This report summarizes the locations of the instruments deployed for this field study, as well as some results from the data. The coordinates have been defined by positioning the instruments within a geographic information systems (GIS) map with a Universal Transverse Mercator (UTM) coordinate system using the 1983 North American Datum (NAD). Geodetic positions are also presented. All latitude values are north of the equator, and all longitude values are west of the prime meridian. The GIS software used for the instrument location refinement was ArcView Version 9.0. In addition to the photographs that documented the instrument positions, the Windows Live Local website (http://local.live.com/) and Google Earth (http://earth.google.com/) were used to refine the coordinates. 


\subsection{Tracer Measurement}

The MSG05 study consisted of two 6-hour-long IOPs. During each IOP, six perfluorocarbon tracers were released simultaneously from five ground-level locations. Figure 2.1 shows a map of the study area with the release locations labeled A through E. The circular MSG building is labeled in the center of the image. The buildings that had rooftop instrumentation are also labeled in this figure. Two different PFT compounds were released from location $\mathrm{C}$ for quality control. Table 2.1 presents the coordinates of each of the release locations. The easting and northing coordinates are for UTM grid zone 18 (NAD 1983).

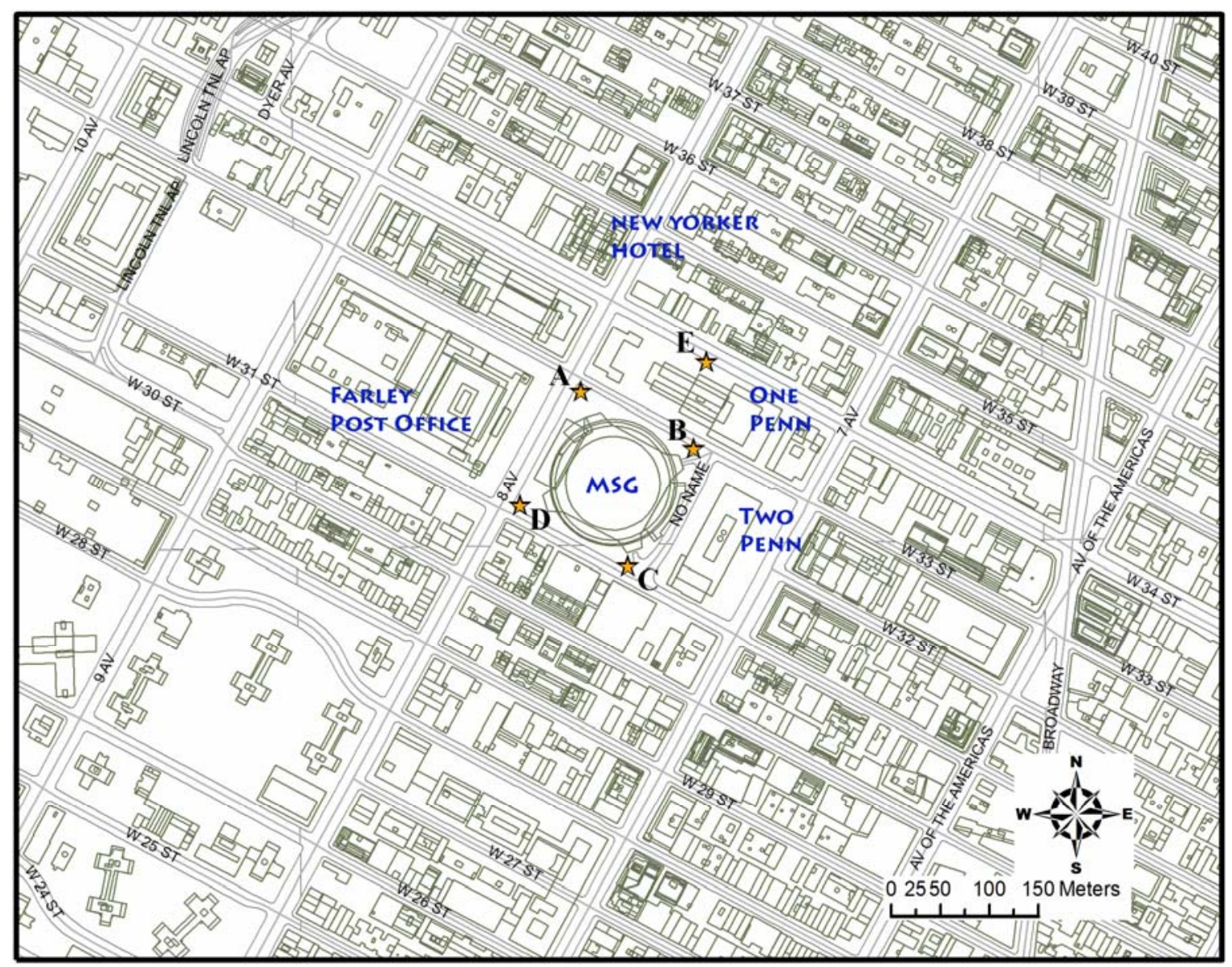

Figure 2.1. Perfluorocarbon Tracer Release Locations

Table 2.1. Release Location Coordinates

\begin{tabular}{|l|l|c|c|c|c||}
\hline \hline Release ID & Location Description & $\begin{array}{c}\text { Latitude } \\
(\mathbf{d e g})\end{array}$ & $\begin{array}{c}\text { Longitude } \\
(\mathbf{d e g})\end{array}$ & $\begin{array}{c}\text { Easting } \\
(\mathbf{m})\end{array}$ & $\begin{array}{c}\text { Northing } \\
(\mathbf{m})\end{array}$ \\
\hline \hline Release A & $8^{\text {th }}$ and $33^{\text {rd }}-$ North corner MSG & 40.75136 & 73.99385 & 584937 & 4511643 \\
\hline Release B & $33^{\text {rd }}$ midway between $7^{\text {th }} \& 8^{\text {th }}$-East corner MSG & 40.75083 & 73.99249 & 585052 & 4511585 \\
\hline Release C & $31^{\text {st }}$ midway between $7^{\text {th }}$ \& ${ }^{\text {th }}$-South corner MSG & 40.74975 & 73.99330 & 584985 & 4511465 \\
\hline Release D & $8^{\text {th }}$ and $31^{\text {st }}-$ West corner MSG & 40.75032 & 73.99460 & 584875 & 4511527 \\
\hline Release E & $3^{\text {th }}$ between $7^{\text {th }} \& 8^{\text {th }}$-middle of Penn One & 40.75162 & 73.99233 & 585065 & 4511673 \\
\hline
\end{tabular}


The ground-level perfluorocarbon tracer samplers in this study were deployed at 19 outdoor locations in two concentric circles, approximately 200 meters and 400 meters from the center of the MSG. Seven sampler sites were also employed on the rooftops of the One Penn Plaza, Two Penn Plaza, Farley Post Office, and New Yorker Hotel. Finally, two samplers were deployed inside MSG itself and one inside the New Yorker Hotel conference room. Figure 2.2 shows the ground-level sampler locations, labeled 1 through 20, and the rooftop samplers, labeled V1 through V7. Table 2.2 shows the coordinates of each of the outdoor sampler locations.

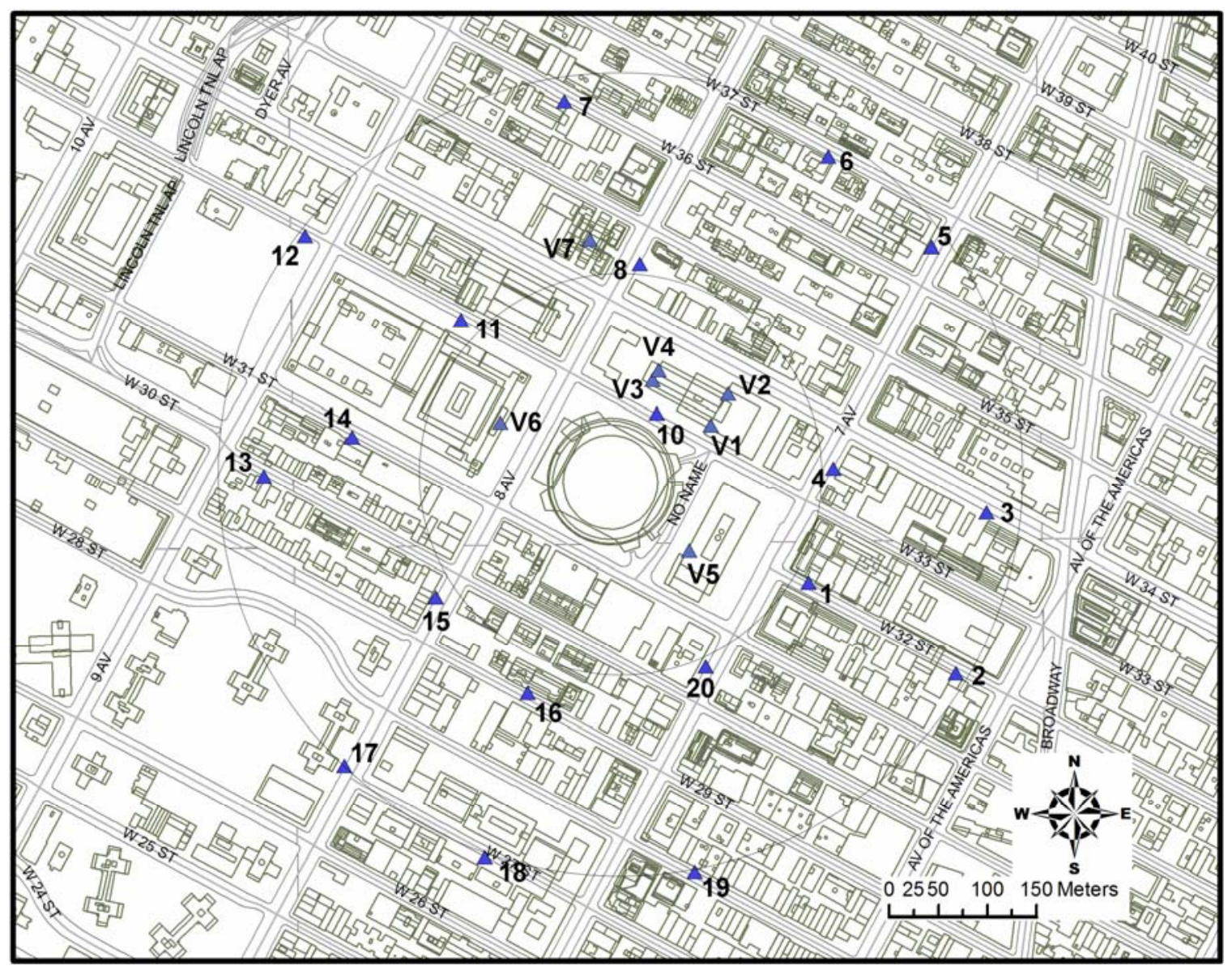

Figure 2.2. Outdoor Perfluorocarbon Tracer Sampler Locations. The two concentric circles represent distances 200 and 400 meters from the center of the MSG.

A number of different tracer-measurement instruments were deployed in support of this field study. These included Brookhaven atmospheric tracer samplers (BATSs), sequential air samplers (SASs), personal air samplers (PASs), and a continuous dual trap analyzer (CDTA). The BATSs were programmed to collect 30-minute samples, while the SASs collected 6-minute samples. The PASs were deployed at many of the ground-level locations as well as in walking paths to investigate personal exposure. Adsorption tubes in the PASs were simply replaced every half-hour by the student participants to produce 30-minute samples. The CDTA was deployed in a mobile van to capture the PFT plumes at time and spatial resolutions that could not be achieved by the stationary samplers. See Watson et al. (2006) for additional details about the tracer instrumentation deployed for this field study. 
Table 2.2. Brookhaven Sampler Coordinates

\begin{tabular}{|c|c|c|c|c|c|}
\hline Sampler \# & Location Description & $\begin{array}{c}\text { Latitude } \\
\text { (deg) }\end{array}$ & $\begin{array}{c}\begin{array}{c}\text { Longitude } \\
\text { (deg) }\end{array} \\
\end{array}$ & $\begin{array}{c}\begin{array}{c}\text { Easting } \\
(\mathrm{m})\end{array} \\
\end{array}$ & $\begin{array}{c}\text { Northing } \\
(\mathbf{m})\end{array}$ \\
\hline$\overline{c 1}$ & $\begin{array}{l}7^{\text {th }} \& 32^{\text {nd }} \text { In front of the Hotel Pennsylvania- } \\
\text { north side of street }\end{array}$ & 40.74957 & 73.99109 & 585172 & 4511447 \\
\hline 2 & $\begin{array}{l}\text { West of } 6^{\text {th }} \& 32^{\text {nd }} \text { in front of the Blarney Stone } \\
\text { Bar-south side }\end{array}$ & 40.74872 & 73.98932 & 585322 & 4511354 \\
\hline 3 & $\begin{array}{l}34^{\text {th }} \& \text { Broadway South side-in front of } \\
\text { Footlocker }\end{array}$ & 40.75019 & 73.98894 & 585353 & 4511518 \\
\hline 4 & $\begin{array}{l}\text { Midway between } 34^{\text {th }} \& 33^{\text {rd }} \text { East side of } 7^{\text {th }} \text {-in } \\
\text { front of McDonald's }\end{array}$ & 40.75061 & 73.99078 & 585197 & 4511563 \\
\hline 5 & $\begin{array}{l}\text { Between } 36^{\text {th }} \& 37^{\text {th }} \text { in front of Bates } \\
\text { Worldwide--west side of } 7^{\text {th }}\end{array}$ & 40.75264 & 73.98956 & 585297 & 4511789 \\
\hline 6 & $\begin{array}{l}232 \text { W. } 37 \text { th south side in front of West Tandoori } \\
\text { Club-midway 7th } \& 8^{\text {th }}\end{array}$ & 40.75349 & 73.99079 & 585192 & 4511882 \\
\hline 7 & $\begin{array}{l}\text { Midway } 8^{\text {th }} \& 9^{\text {th }} \text { on } 36^{\text {th }} \text { in front of } 320 \text { Goldie } \\
\text { Restaurant-South side }\end{array}$ & 40.75402 & 73.99397 & 584923 & 4511938 \\
\hline 8 & $\begin{array}{l}\text { In front of McDonald's Midway } 34^{\text {th }} \& 35^{\text {th }} \text { —east } \\
\text { side of } 8^{\text {th }}\end{array}$ & 40.75251 & 73.99308 & 585000 & 4511772 \\
\hline 10 & $\begin{array}{l}\text { One Penn Plaza—middle of building north side of } \\
33^{\text {rd }}\end{array}$ & 40.75113 & 73.99290 & 585017 & 4511619 \\
\hline 11 & $\begin{array}{l}\text { In front of the Post Office, south side of } 33^{\text {rd }}- \\
\text { between } 8^{\text {th }} \& 9^{\text {th }}\end{array}$ & 40.75201 & 73.99525 & 584818 & 4511714 \\
\hline 12 & $\begin{array}{l}\text { Across from St. Michael's Church, south side of } \\
33^{\text {rd }}-\text { between } 9^{\text {th }} \& 10^{\text {th }}\end{array}$ & 40.75280 & 73.99712 & 584659 & 4511800 \\
\hline 13 & $\begin{array}{l}9^{\text {th }} \text { and } 30^{\text {th }} 370 \mathrm{~W} .30^{\text {th }} \text { — south side of } 30^{\text {th }} \text {, close } \\
\text { to } 9^{\text {th }}\end{array}$ & 40.75060 & 73.99765 & 584617 & 4511555 \\
\hline 14 & $\begin{array}{l}\text { South side of 31st midway } 8^{\text {th }} \& 9^{\text {th }} \text { —across from } \\
\text { bay } 16 \text { of the Post Office }\end{array}$ & 40.75095 & 73.99658 & 584707 & 4511595 \\
\hline 15 & $\begin{array}{l}\text { West side of } 8^{\text {th }} \# 393 \text { midway between } 30^{\text {th }} \& \\
29^{\text {th }} \text {-in front of } 8^{\text {th }} \text { Ave Garden }\end{array}$ & 40.74947 & 73.99559 & 584792 & 4511432 \\
\hline 16 & $\begin{array}{l}\text { In front of } 29^{\text {th }} \text { St Marketplace, north side of } \\
29^{\text {th }}-\text { between } 7^{\text {th }} \& 8^{\text {th }}\end{array}$ & 40.74858 & 73.99449 & 584886 & 4511334 \\
\hline 17 & $\begin{array}{l}8^{\text {th }} \& 27^{\text {th }} \text {, middle of T-bone intersection-west } \\
\text { side } 8^{\text {th }}\end{array}$ & 40.74793 & 73.99672 & 584699 & 4511260 \\
\hline 18 & In front of Nagler Hall on the south side of $27^{\text {th }}$ & 40.74708 & 73.99504 & 584842 & 4511167 \\
\hline 19 & $\begin{array}{l}\text { North side of } 28^{\text {th }} \text { in front of Center Floral } \\
\text { Design-between } 6^{\text {th }} \& 7^{\text {th }}\end{array}$ & 40.74692 & 73.99250 & 585056 & 4511152 \\
\hline 20 & $\begin{array}{l}\text { In front of Seven Penn Plaza between } 30^{\text {th }} \& \\
31^{\text {st }} \text { - west side of } 7^{\text {th }}\end{array}$ & 40.74881 & 73.99234 & 585067 & 4511361 \\
\hline V1 & 12th story Penn One $33^{\text {rd }}$ Street side & 40.75102 & 73.99225 & 585072 & 4511607 \\
\hline V2 & 12th story Penn One $34^{\text {th }}$ Street side & 40.75131 & 73.99203 & 585090 & 4511639 \\
\hline V3 & Top of Penn One $33^{\text {rd }}$ Street side & 40.75144 & 73.99294 & 585013 & 4511653 \\
\hline V4 & Top of Penn One $34^{\text {th }}$ Street side & 40.75153 & 73.99287 & 585019 & 4511663 \\
\hline V5 & Top of Penn Two & 40.74987 & 73.99253 & 585050 & 4511479 \\
\hline V6 & Top of Post office $8^{\text {th }}$ and $33^{\text {rd }}$ & 40.75107 & 73.99479 & 584858 & 4511610 \\
\hline V7 & Top of New Yorker Hotel & 40.75274 & 73.99368 & 584949 & 4511796 \\
\hline
\end{tabular}




\subsection{Quality-Assured Tracer Dataset}

The perfluorocarbon concentration data collected from the BATS instruments have been thoroughly quality-assured for use in model validation efforts. Background concentrations have been removed to retain only those measurements that result from the PFT releases. The method for determining the background concentration involved plotting all of the BATSs and visually filtering the data to eliminate outliers and high concentrations, retaining only a band of data that appeared to be the background/noise. The average of the background/noise was then subtracted from the data to produce values that represent the portion of the ambient PFT concentration that is attributable to the tracer release.

The total set of quality-assured BATS data include 15 ground-level samplers (plus one duplicate), five rooftop samplers, and one indoor sampler for IOP 1. IOP 2 had data from 16 ground-level samplers (plus one duplicate) and seven rooftop locations. This quality-assured BATS dataset for model validation efforts is available as an Excel file. Details about the quality-assurance procedures applied to this verified dataset can be found on the "Info" tab of the Excel workbook that contains these data. For completeness, also included in this Excel file are the PFT release rates from Table 3 in Watson et al. (2006). The MSG05 tracer data currently have limited distribution, and will only be distributed with a needto-know. The data will be available from a secure database in the future. At this time, individuals may request the data by contacting the authors at jerry.allwine@pnl.gov or julia.flaherty@pnl.gov. 


\subsection{Meteorological Measurements}

Meteorological measurements were made by several street-level, building setback, and building rooftop wind stations. Three sodars were also deployed to measure vertical wind profiles. Many of the instruments were deployed near MSG to characterize the local flow patterns that affect plume transport. Figure 4.1 presents a map with the meteorological instruments that were deployed near MSG.

The street-level sonic anemometers, labeled s1 through s5 and s7 in Figure 4.1, were deployed on 3-m aluminum tripods. The rooftop stations, on the other hand, were mounted on 6-m tripods of similar construction. Building setback stations, such as s6, r6, and r7, were mounted on booms. The meteorological instruments in the near-field were deployed by BNL. See Reynolds (2006) for additional details concerning meteorological instruments deployed by BNL.

Winds were also measured at a location across the Hudson River, west of Manhattan. Two sodars and a meteorological tower were located at the Stevens Institute of Technology (SIT) in Hoboken, New Jersey. See Berg et al. (2006) and Berg and Allwine (2006) for a description of the sodars deployed at SIT.

In addition to the meteorological instruments that were deployed specifically to support this field study, permanent instruments continuously collected data that are available for analysis. These permanent installations include the National Oceanic and Atmospheric Administration (NOAA) and DCNet instruments and the ASOS. Figure 4.2 shows a map of the instruments deployed on and around Manhattan. Figure 4.3 shows an overview of all the NWS ASOS stations around NYC. Table 4.1 gives the coordinates of each of the meteorological instruments shown in Figure 4.1 to Figure 4.3.

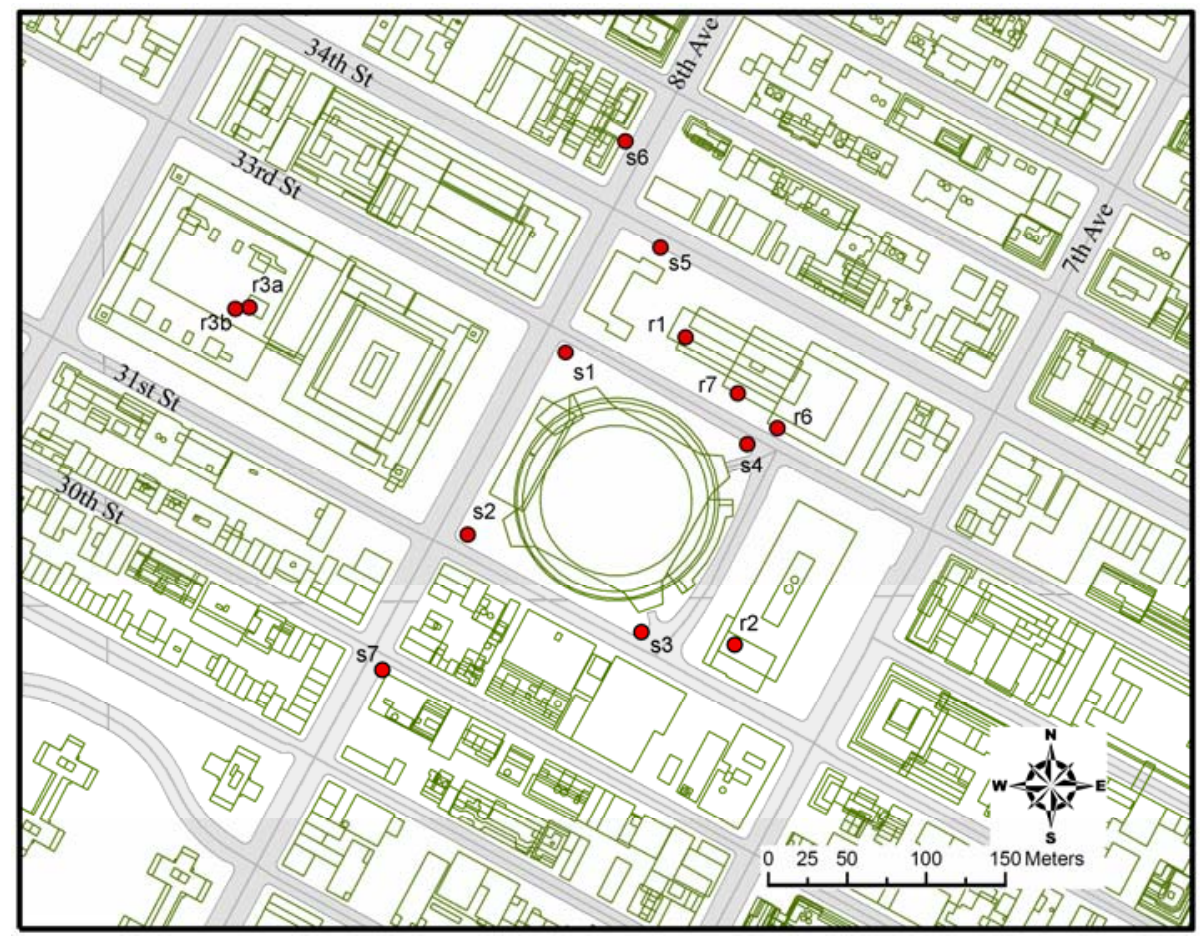

Figure 4.1. Sonic Anemometer Locations in the Vicinity of MSG 


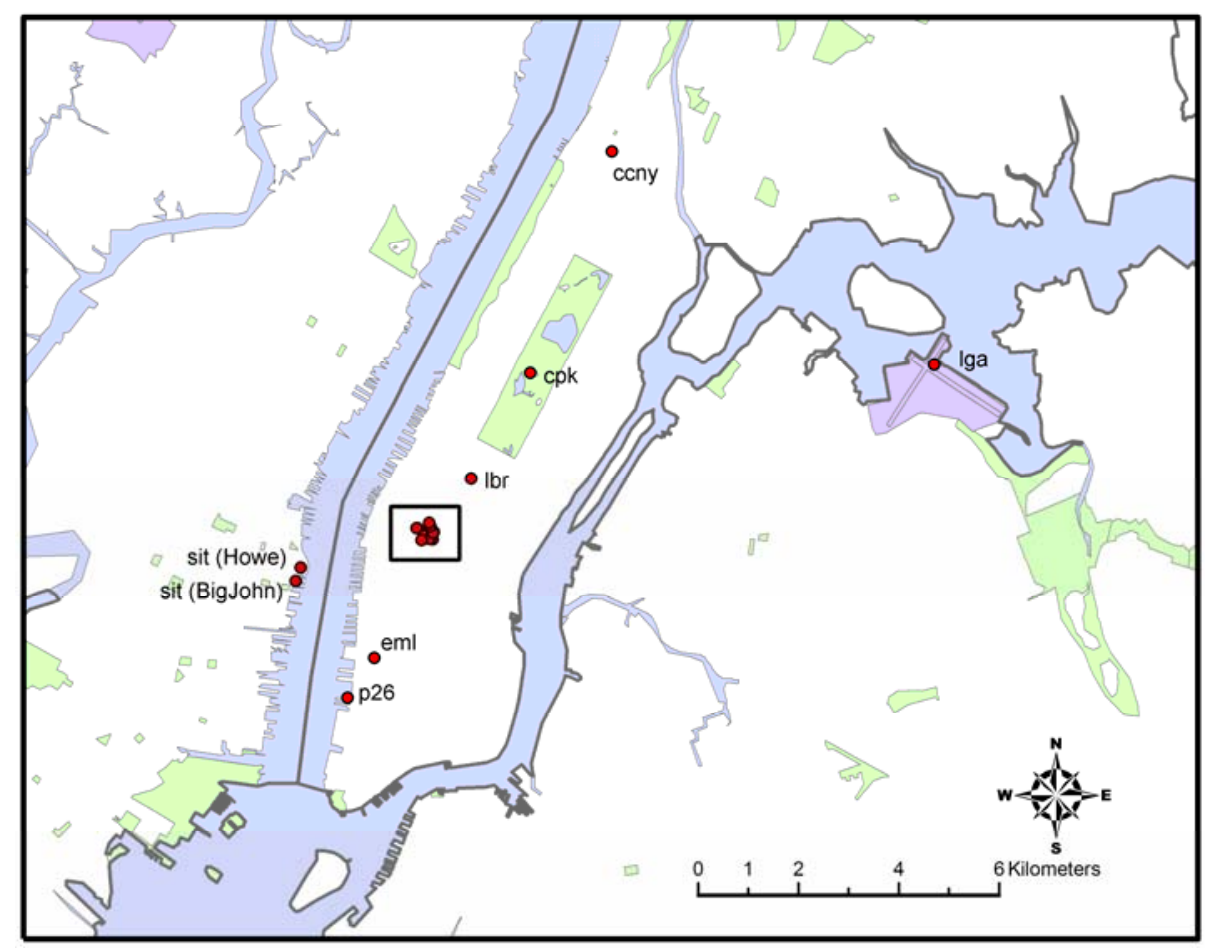

Figure 4.2. Meteorological Stations in the Vicinity of Manhattan. The small box southwest of lbr represents the area shown in Figure 4.1.

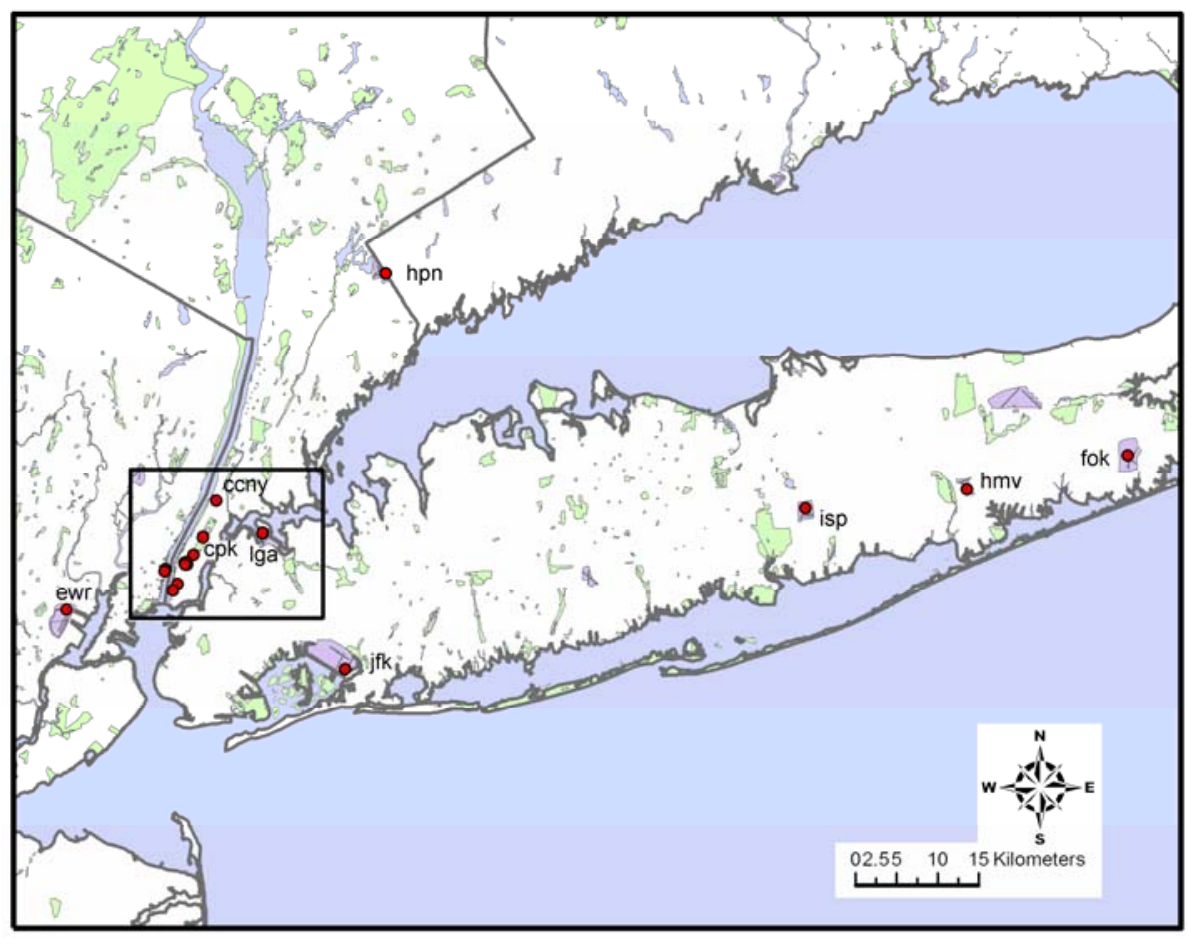

Figure 4.3. Overview of All Meteorological Stations in the Vicinity of NYC. The box in the western portion of the image, east of ewr, represents the area shown in Figure 4.2. 
Table 4.1. Meteorological Instrument Coordinates

\begin{tabular}{|c|c|c|c|c|c|}
\hline Station Name & Location Description & $\begin{array}{c}\begin{array}{c}\text { Latitude } \\
\text { (deg) }\end{array} \\
\end{array}$ & $\begin{array}{c}\text { Longitude } \\
\text { (deg) }\end{array}$ & $\begin{array}{c}\text { Easting } \\
\text { (m) }\end{array}$ & $\begin{array}{c}\text { Northing } \\
\text { (m) }\end{array}$ \\
\hline NOAA-ccny & CCNY $^{(\mathrm{a})}$ Roof NOAA GPS station & 40.81923 & 73.94911 & 588623 & 4519222 \\
\hline ASOS-cpk & Central Park NOAA ASOS & 40.77944 & 73.96907 & 586992 & 4514785 \\
\hline DCNet-eml & Environ Meas Lab 15th floor roof & 40.72838 & 74.00666 & 583884 & 4509080 \\
\hline ASOS-ewr & Newark Airport ASOS & 40.69250 & 74.16868 & 570240 & 4504955 \\
\hline ASOS-fok & Westhampton Gabreski Airport & 40.84999 & 72.63334 & 699499 & 4524801 \\
\hline ASOS-hpn & White Plains Westchester Co Airport & 41.06667 & 73.70000 & 609223 & 4546972 \\
\hline ASOS-hwv & Shirley Brookhaven Airport & 40.81667 & 72.86667 & 679919 & 4520596 \\
\hline ASOS-isp & Islip Long Island Macarthur Airport & 40.80000 & 73.10000 & 660279 & 4518292 \\
\hline ASOS-jfk & New York JFK International Airport & 40.63333 & 73.76667 & 604299 & 4498786 \\
\hline DCNet-lbr & Lehman Brothers roof & 40.76049 & 73.98326 & 585819 & 4512667 \\
\hline ASOS-lga & New York LaGuardia Airport & 40.78006 & 73.87345 & 595060 & 4514953 \\
\hline MESO-p26 & Pier 26 Hudson River & 40.72122 & 74.01311 & 583348 & 4508279 \\
\hline ROOF-r1 & One Penn Plaza Roof & 40.75144 & 73.99293 & 585014 & 4511652 \\
\hline ROOF-r2 & Two Penn Plaza roof & 40.74967 & 73.99259 & 585045 & 4511457 \\
\hline ROOF-r3a & Farley $\mathrm{PO}^{(\mathrm{b})}$ met station & 40.75164 & 73.99620 & 584738 & 4511672 \\
\hline SODAR-r3b & Farley PO sodar & 40.75163 & 73.99631 & 584729 & 4511671 \\
\hline SBACK-r6 & One Penn Plaza 7th floor setback & 40.75091 & 73.99225 & 585072 & 4511595 \\
\hline SBACK—r7 & One Penn Plaza 12th floor setback & 40.75111 & 73.99255 & 585047 & 4511617 \\
\hline STREET—s1 & NW corner of MSG & 40.75136 & 73.99383 & 584938 & 4511643 \\
\hline STREET-s2 & SW corner of MSG & 40.75032 & 73.99458 & 584876 & 4511527 \\
\hline STREET-s3 & SE corner of MSG & 40.74975 & 73.99329 & 584986 & 4511465 \\
\hline STREET—s4 & NE corner of MSG & 40.75082 & 73.99248 & 585053 & 4511585 \\
\hline STREET-s5 & $34^{\text {th }}$ St N of One Penn Plaza & 40.75196 & 73.99311 & 584998 & 4511709 \\
\hline SBACK-s6 & NY Hotel Overhang $\left(8^{\text {th }}\right.$ Ave $)$ & 40.75257 & 73.99337 & 584976 & 4511778 \\
\hline STREET—s7 & SE corner $8^{\text {th }}$ and $30^{\text {th }}$ & 40.74955 & 73.99523 & 584822 & 4511441 \\
\hline MESO-sit & Stevens Institute of Tech Howe Ctr & 40.74486 & 74.02384 & 582413 & 4510893 \\
\hline miniSodar-sit & Stevens Institute of Tech Howe Ctr & 40.74486 & 74.02384 & 582413 & 4510893 \\
\hline SODAR-sit & Stevens Institute of Tech Big John & 40.74242 & 74.02505 & 582314 & 4510621 \\
\hline
\end{tabular}




\subsection{Initial Results}

During each of the two study days of the MSG experiment, the overall wind conditions were generally constant through the 6-hr study period. The first study day (IOP 1) experienced winds that were nearly parallel to the streets, at about 300 degrees. Figure 5.1 shows the wind speeds and directions from four elevated measurements: 30-minute averages from the 90-meter range gate of the SIT Sodar on Howe Center, 5-minute averages from the roof of One Penn Plaza, the roof of the Farley Post Office, and the roof of Two Penn Plaza. The yellow bars on the figure represent each of the hour-long tracer release periods, and all times are presented in Eastern Standard Time. The SIT sodar was west of the MSG study area, across the Hudson River (see Figure 4.2), and this supports the fact that the rooftop measurements near MSG represent mean above-city flows. The wind directions are similar between the four measurement locations, and the wind speeds increase with the height of the measurement. The average temperature and pressure during the first release period of IOP 1 was about $-3.8^{\circ} \mathrm{C}$, and $1003 \mathrm{mb}$, respectively. Conditions were similar during the second release period, with average temperature and pressure approximately $-2.2^{\circ} \mathrm{C}$ and $1002 \mathrm{mb}$.
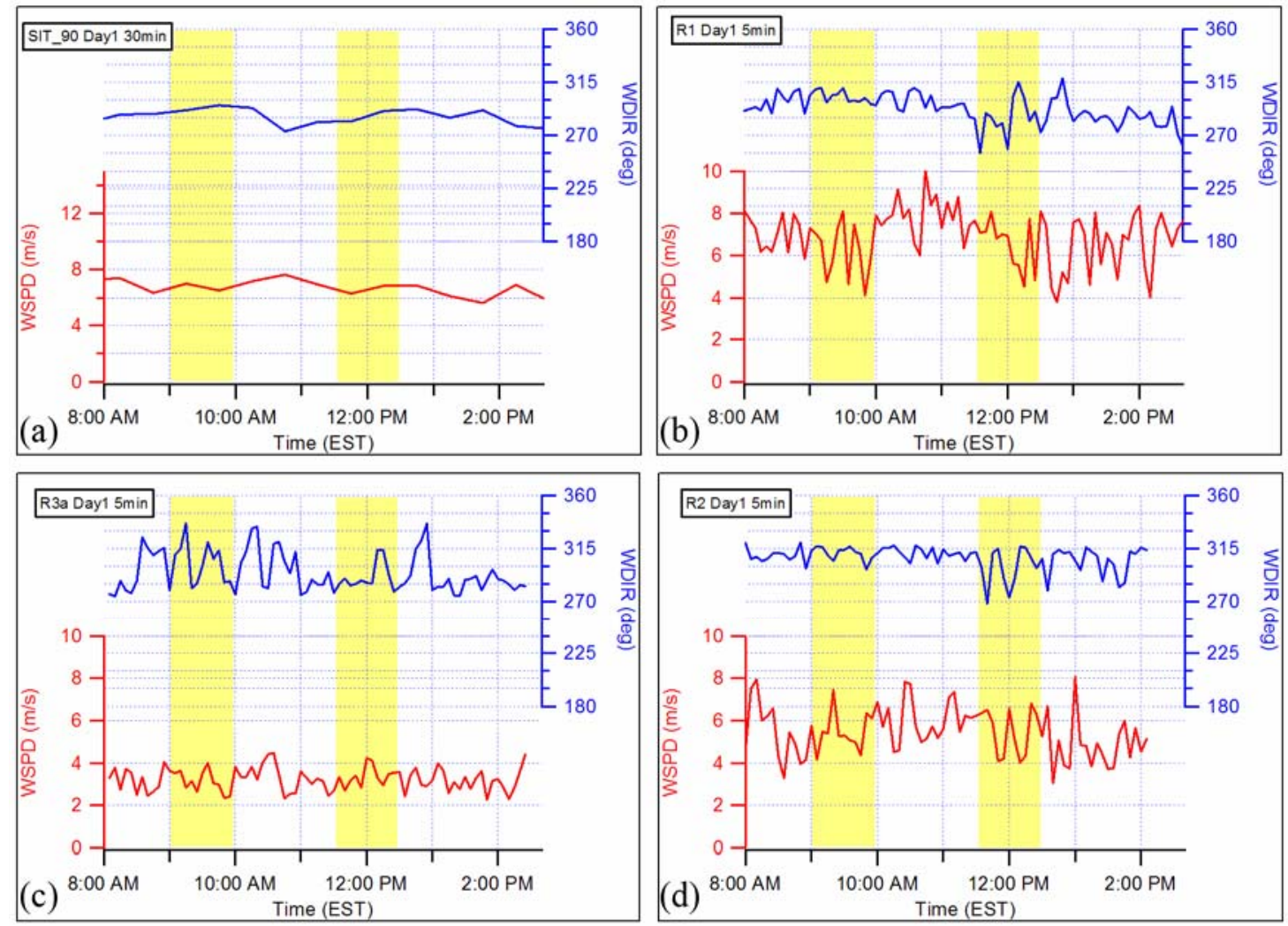

Figure 5.1. IOP 1 Winds from (a) the $90-\mathrm{m}$ Level (175m above mean sea level [AMSL]) of the AeroVironment (AV) Sodar at SIT, Rooftop Meteorological Stations at (b) One Penn Plaza (240m AMSL), (c) Farley Post Office (47m AMSL), and (d) Two Penn Plaza (146m AMSL). Yellow bars represent the two 1-hour tracer release periods. WSPD means "wind speed," and WDIR means "wind direction." 
Figure 5.2 presents time series plots of the four street-level sonic anemometers that were deployed on the street corners around MSG. The two sites to the west of MSG, s1 and s2, indicate that the flow is diffluent at the MSG and forces channeling in opposite directions along $8^{\text {th }}$ Avenue. Location s3, which was between MSG and Two Penn Plaza, appears to be influenced by flows traveling down the windward face of Two Penn Plaza and away from the building, towards MSG near the ground surface. The winds at the final sonic anemometer location of Figure 5.2, s4, are less steady than the previous three locations. Winds at s4 tend to switch between southerly and northerly at time intervals between 5 and 30 minutes.
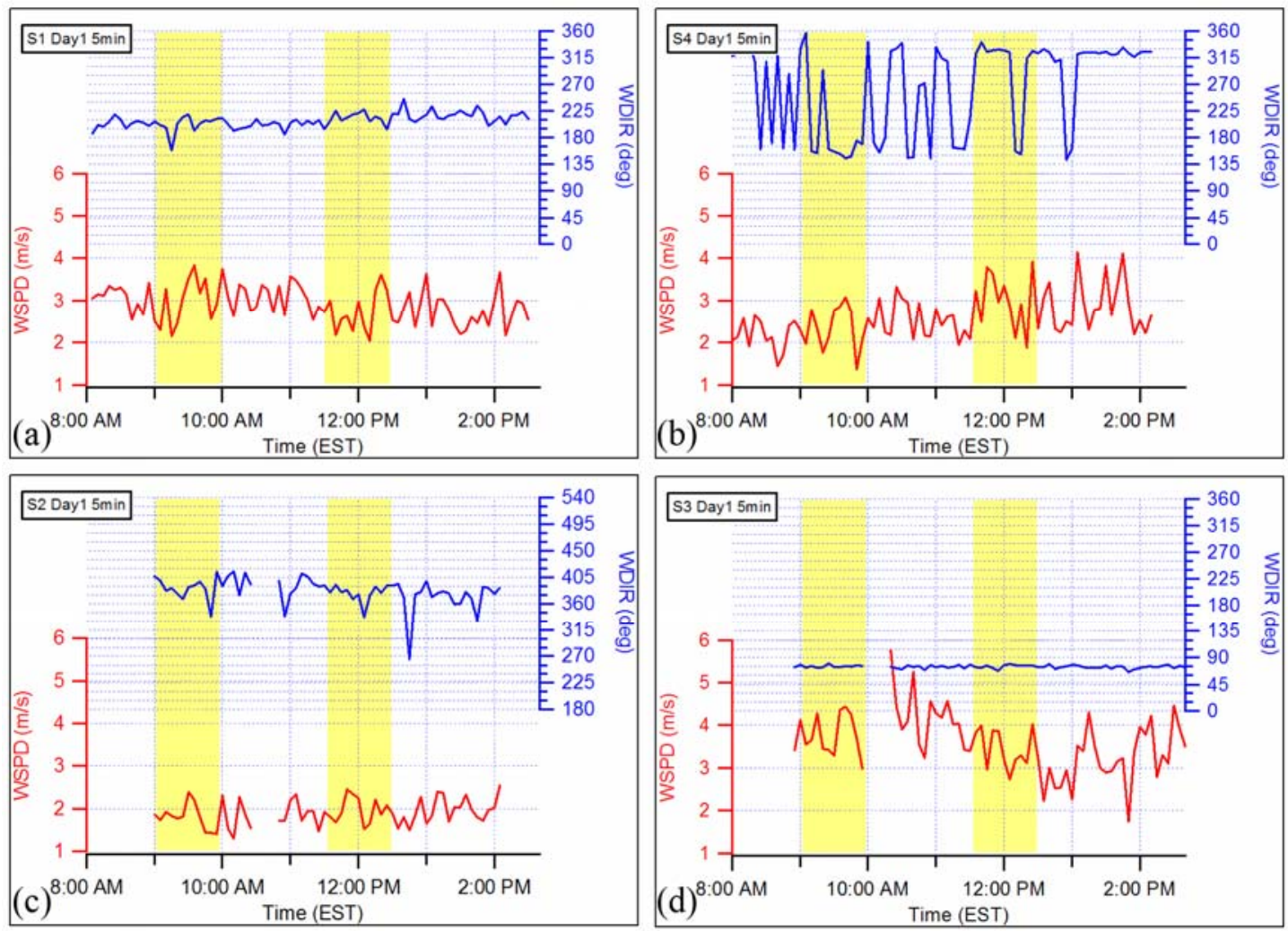

Figure 5.2. IOP 1 Winds from the Street Level Sonic Anemometers Surrounding MSG on the (a) Northwest, (b) Northeast, (c) Southwest, and (d) Southeast Corners. Yellow bars represent the two 1-hour tracer release periods. WSPD means "wind speed," and WDIR means "wind direction."

The average of four 30-minute BATS measurements for the two hour-long tracer release periods was computed. The background concentration was removed from the BATS measurements so that only the concentrations that were attributable to the tracer release were used. These average values were then plotted on a map to develop an estimate of the plume footprint for each of the five tracer release positions. Figure 5.3 presents the results of these contours. To protect the sensitive nature of these concentration results, the contour intervals have been intentionally omitted from this figure. In addition to the plume footprints, Figure 5.3 shows the vector-averaged wind speed and direction for the measurement locations near MSG during the same 2-hour period. The variability in winds during these two-hour periods are represented by wedges that are two standard deviations of the wind direction. 

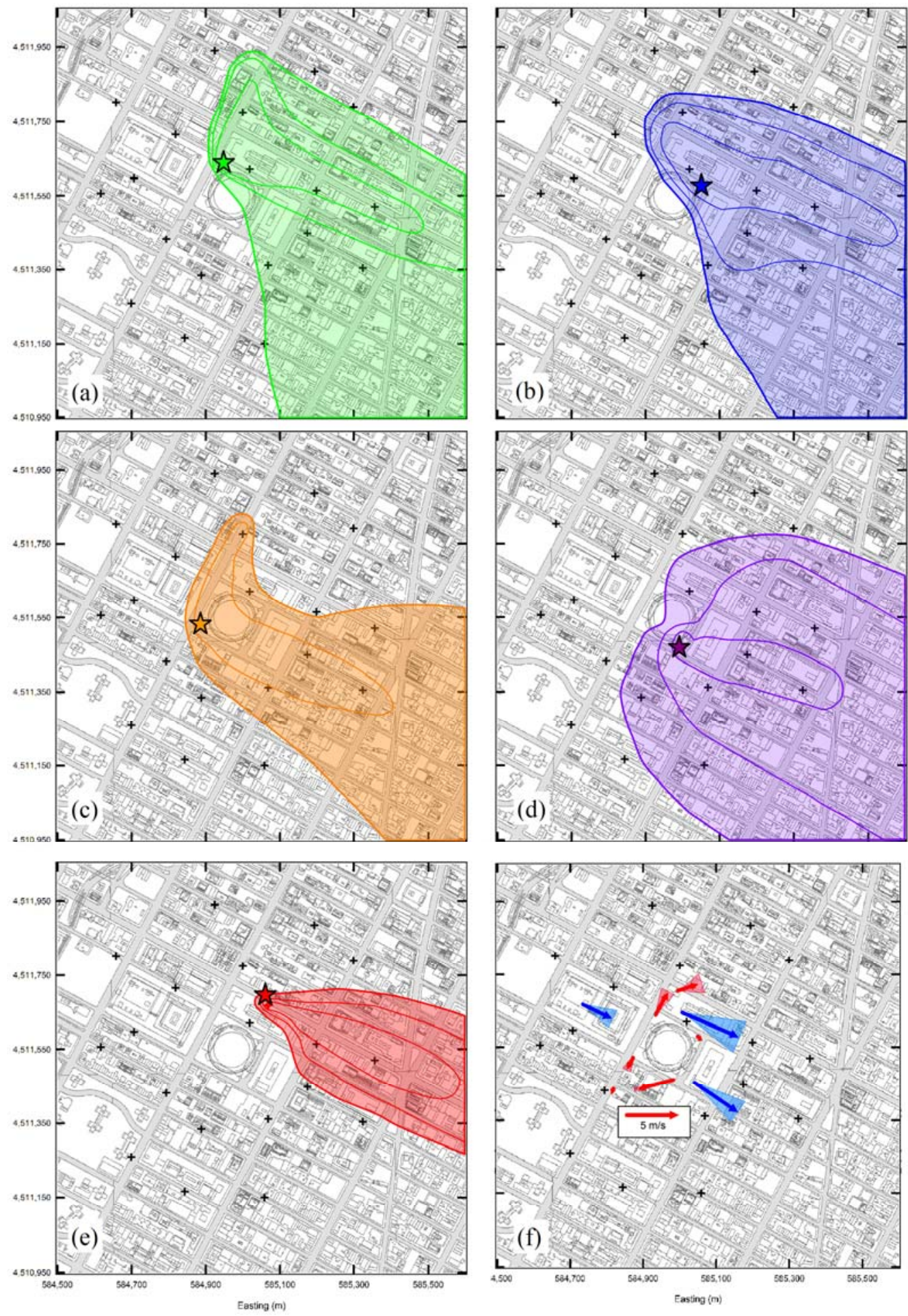

Figure 5.3. IOP 1 Plume Contours Based on the Average of Two Separate Hours of Tracer Release for Various Release Locations. (a) Release A, (b) Release B, (c) Release D, (d) Release C, (e) Release E, and (f) average wind speed and direction with wedges representing two standard deviations of wind direction. Blue arrows represent building-top winds and red arrows represent street-level winds. 
Figure 5.3 shows that there are vastly different plume footprints for each of the release locations. In general, there is a fair amount of upwind and/or crosswind transport of tracer material. The exception to this is the tracer release from location E, which was on the north side of One Penn Plaza. It appears that the tracer is mostly channeled downwind along the street from this location because the winds were aligned with the streets.

The second study day (IOP 2) experienced winds that were at an angle to the streets, at about 330 degrees. Figure 5.4 shows the wind speeds and directions from four elevated measurements: the 90-meter range gate of the SIT Sodar on Howe Center, the roof of One Penn Plaza, the roof of the Farley Post Office, and the roof of Two Penn Plaza. Compared with IOP 1, the wind measurements at the SIT sodar were commensurate with the measurements made near MSG. The wind directions are similar between the three near-MSG measurement locations, and the wind speeds increase with the height of the measurement. Average temperatures during the tracer release periods of the second IOP were $-0.6^{\circ} \mathrm{C}$ and $1.5^{\circ} \mathrm{C}$ for the first and second release periods, respectively. The average pressures during these periods were $1008 \mathrm{mb}$ and $1007 \mathrm{mb}$.
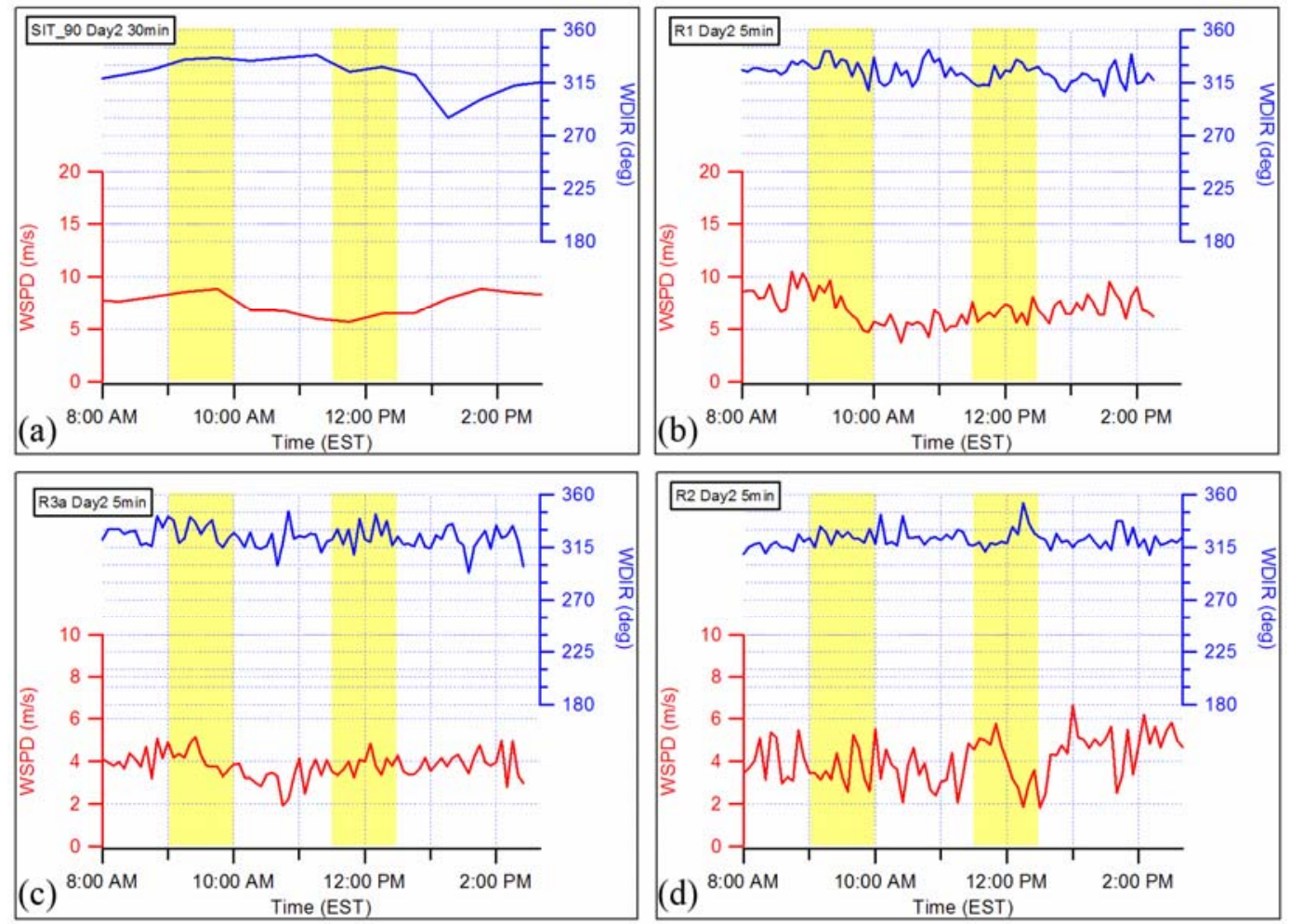

Figure 5.4. IOP 2 Winds from (a) the 90-m Level (175m AMSL) of the AV Sodar at SIT, Rooftop Meteorological Stations at (b) One Penn Plaza (240m AMSL), (c) Farley Post Office (47m AMSL), and (d) Two Penn Plaza (146m AMSL). Yellow bars represent the two 1-hour tracer release periods. WSPD means "wind speed,” and WDIR means "wind direction."

Figure 5.5 presents time series plots of the four street-level sonic anemometers that were deployed on the street corners around MSG for the second study day (IOP 2). As was seen during IOP 1, the two sites to the west of the MSG (s1 and s2) indicate flow divergence at MSG with channeling in opposite directions. However, the winds at s2 were not as steady as during the first day, and winds shifted between 
40 degrees and 195 degrees. Although location s3 experienced very steady winds during IOP 1, this location had highly variable wind directions during IOP 2. Winds at s3 shifted from about 90 to 270 degrees at intervals between about 30 and 60 minutes. This is a potential indicator of a recirculation zone behind the Madison Square Garden, or simply intermittency between flow channeling down $31^{\text {st }}$ Street and flow away from Two Penn Plaza. Unlike the conditions during IOP 1, the sonic anemometer at s4 experienced very constant wind directions and periodicity in wind speeds during IOP 2. The winds at s4 were generally from 165 degrees, which is nearly 180-degrees from the mean above-city wind direction. In this case, s4 may have been experiencing flow that was deflected away from Two Penn Plaza.
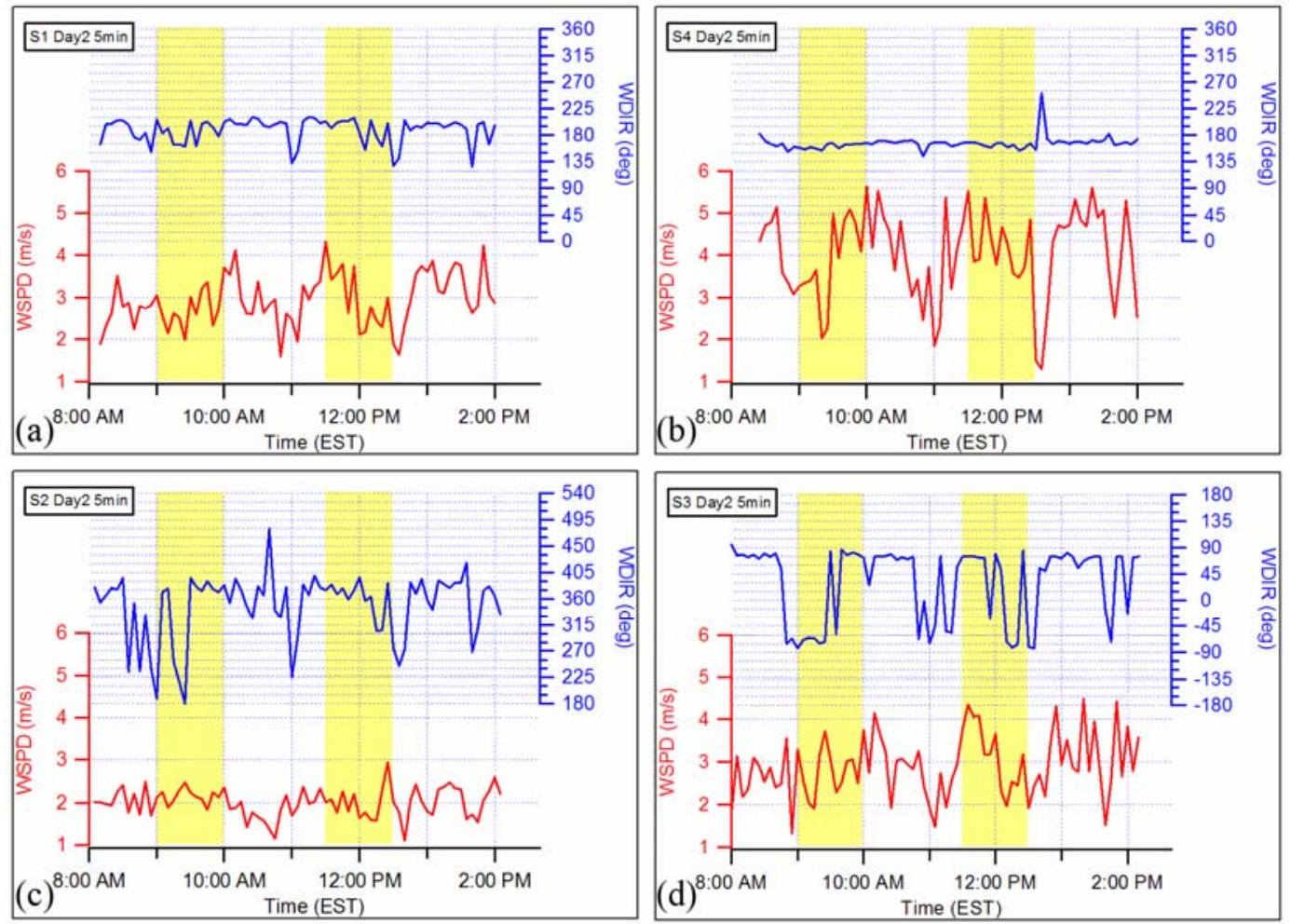

Figure 5.5. IOP 2 Winds from the Street Level Sonic Anemometers Surrounding MSG on the (a) Northwest, (b) Northeast, (c) Southwest, and (d) Southeast Corners. Yellow bars represent the two 1-hour tracer release periods. WSPD means "wind speed," and WDIR means "wind direction."

Figure 5.6 presents the average BATSs and wind measurements from the two hour-long tracer release periods for IOP 2. As was shown in Figure 5.3 for the first study day, there is a variety of different plume footprint shapes and a fair amount of upwind and/or crosswind transport of tracer for the different release locations. In general, the overall extent of the plume was similar in shape between the two IOPs. The exception to this is that the release from location D (southwest corner of MSG) did not have the crosswind transport near the source that was seen during IOP1. Also, although release E (north of One Penn) during IOP 2 exhibited a similar initial channeling down $34^{\text {th }}$ Street as was observed during IOP 1 , the plume became broader in the first block downwind from the source. 

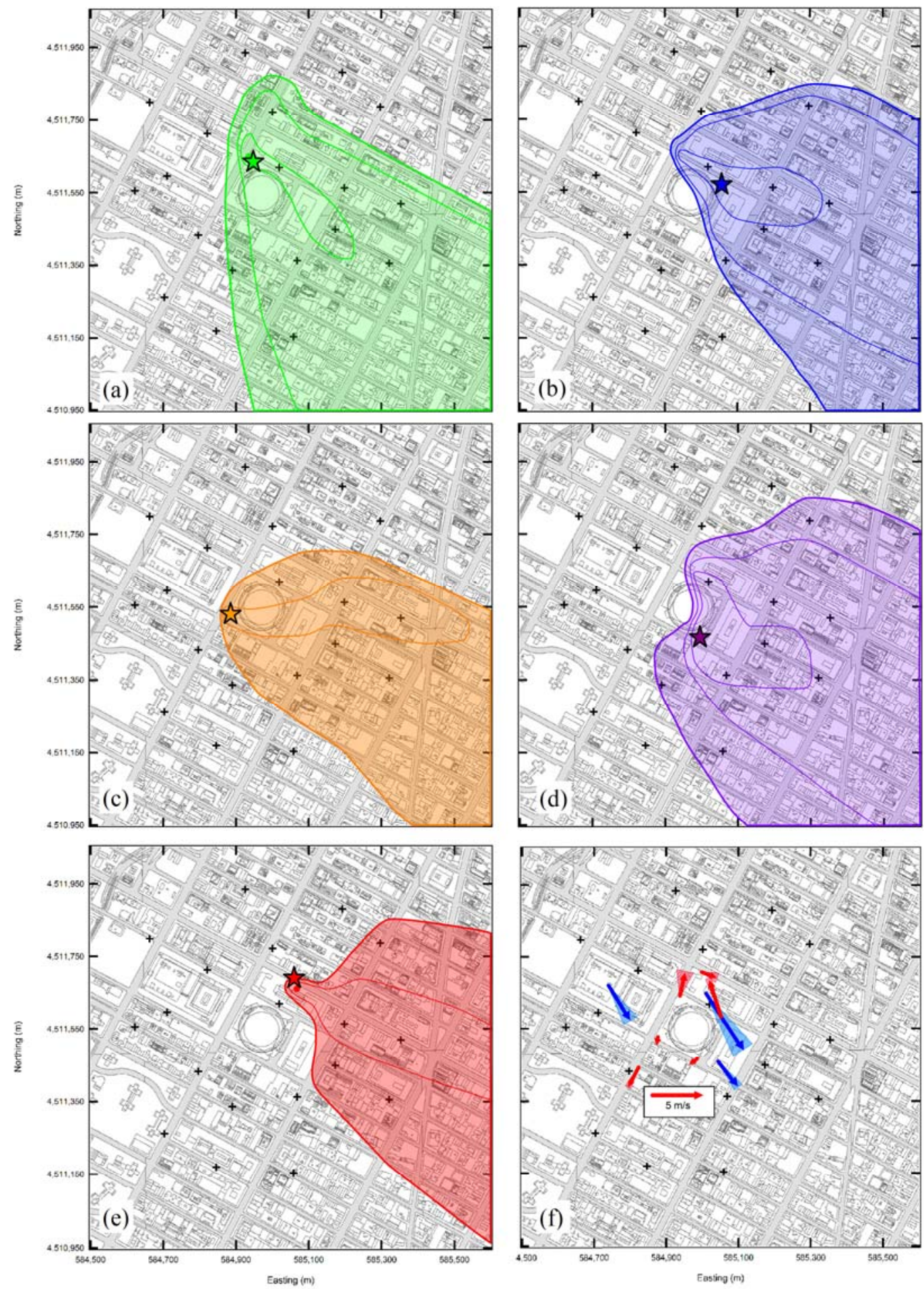

Figure 5.6. IOP 2 Plume Contours Based on the Average of Two Separate Hours of Tracer Release for Various Release Locations. (a) Release A, (b) Release B, (c) Release D, (d) Release C, (e) Release E, and (f) average wind speed and direction with wedges representing two standard deviations of wind direction. Blue arrows represent building-top winds and red arrows represent street-level winds. 


\subsection{References}

Berg LK, and KJ Allwine. 2006. Deployment Notes for Sodars at the Stevens Institute for Technology During the March 2005 Urban Dispersion Program Field Campaign (MSG05). PNNL-19545, Pacific Northwest National Laboratory, Richland, WA.

Berg LK, RM Reynolds, KJ Allwine, and A Blumberg. 2006. Comparisons of Measurements made using Two Sodars in an Urban Environment. Preprints, $86^{\text {th }}$ AMS Annual Meeting, Atlanta, GA, Amer. Meteor. Soc., JP2.9

Reynolds RM. 2006. The Madison Square Garden Dispersion Study (MSG-05) Meteorological Data Report. BNL Interim Report, Brookhaven National Laboratory, Upton, NY.

Watson TB, J Heiser, P Kalb, RN Dietz, R Wilke, R Wieser, and G Vignato. 2006. The New York City Urban Dispersion Program March 2005 Field Study: Tracer Methods and Results.

BNL-75592-2006, Brookhaven National Laboratory, Upton, NY. 


\section{Distribution}

No. of

Copies

\section{OFFSITE}

1 Tom Watson

Brookhaven National Laboratory

P.O. Box 5000

Upton, NY 11973-5000

(631) 344-4517

1 Donny Storwold

U.S. Army Dugway Proving Ground

Meteorology Division

CSTE-DTC-DP-ME-M

Building 4034 / Room 111

Dugway, UT 84022-5000

(435) 821-5496

1 Tom Kiess

Department of Homeland Security

Attn: S\&T/Tom Kiess/4-6015

Anacostia Naval Annex

245 Murray Lane, SW, Building 410

Washington, DC 20528

(202) 254-6015

[send FedEx/UPS]

\section{ONSITE}

13 Pacific Northwest National Laboratory

K.J. Allwine (10) K9-30

J.E. Flaherty (1) K9-30

Information Release (2) P8-55

Distr. 1 